\title{
Clinico-mycological study of Dermatophytosis at a tertiary medical center of Uttar Pradesh
}

\author{
Gupta S.K. ${ }^{1}$, Prasad J. ${ }^{2}$, Brahmane R. B. ${ }^{3}$ \\ ${ }^{1}$ Dr. Sunil Kumar Gupta, Associate Professor, Department of Dermatology, Veneriology \& Leprosy, ${ }^{2}$ Dr. Jitendra Prasad, \\ Junior Resident, Department of Microbiology, ${ }^{3}$ Dr. R. B. Brahmane, Professor, Department of Microbiology, all authors \\ are affiliated with HIMS Safedabad, Barabanki,UP, India.
}

Address for Correspondence: Dr. Sunil Kumar Gupta, Associate Professor, Department of Dermatology, Veneriology \& Leprosy HIMS Safedabad, Barabanki. Email: dr.sunil_30@yahoo.co.in

\begin{abstract}
Background: Now day's number of dermatophyte infection in general population is increasing. It is generally known as Tinea corporis, Tinea cruris, Tinea faciei etc. Material and Methods: A prospective study was done to know the current clinical status of dermatophytic infection in patients attending the outpatient department of skin at a tertiary medical center. Mycological study of skin scraping was done in department of Microbiology.The data was interpreted by statics. Result: In the present study, most common age group affected 21-30 years with $37.90 \%$. Male to female ratio was $4.7: 1$. Dermatophytoses infection was found to be higher among manual worker $(40.1 \%)$ and in lower middle class $(52 \%$ cases). Tinea corporis and Tinea cruris were the most common clinical type (48\%). KOH positivity was seen in $78.8 \%$ of cases. Conclusion: Dermatophyte infection is quite prevalent now days. It is more in middle age group with male preponderance. It is more commonly seen in lower middle class and mostly in manual workers. Tinea corporis et cruris is the commonest presentation.
\end{abstract}

Key words: Dermatophytes, Tinea corporis, Tinea cruris, Tinea faciei, Tinea unguium.

\section{Introduction}

Superficial fungal infections are the most common skin disease affecting millions of people throughout the world. The majority of these infections are caused by dermatophytes [1]. Dermatophytes are a group of closely related keratinophilic fungi, all of which produce keratinase that can invade the stratum corneum of skin or other keratinized tissues derived from epidermis such as hair and nails.

Dermatophytesis an infection produced by a dermatophytic fungus in the keratinized tissues - hair, nails and stratum corneum of skin[1]. Dermatophytosis is generally called "tinea" or "ringworm". Tinea is Latin for 'larva of small insect'.

The common clinical term given to dermatophytosis is designated by appending Latin word to an anatomical site at which infection is present to the term tinea. The

Manuscript received: $14^{\text {th }}$ August 2017

Reviewed: $24^{\text {th }}$ August 2017

Author Corrected: $1^{\text {st }}$ September 2017

Accepted for Publication: $8^{\text {th }}$ September 2017 distribution of different species of dermatophytes varies markedly form one ecological niche to another depending on their primary natural habitat. Certain species of dermatophytes are geographically restricted and endimic only in particular parts of world while some species are sporadic but worldwide in distribution [1].

The prevalence of dermatophytosis is governed by environmental conditions, personal hygiene and individual susceptibility from place to place [2].

\section{Material and Methods}

Study site: This prospective study was conducted in the Department of Dermatology and Microbiology, HIMS, Safedabad, Barabanki, U.P.

Study Population: The study was conducted on samples of skin scrapping, nail, hair and hair roots received to the laboratory. 
Study Design: Prospective study.

Sample Size: In a previous study by Mahale et al (2014), of the 177 samples, 115 (65\%) were $\mathrm{KOH}$ positive. At $95 \%$ confidence level and $80 \%$ power the formula for calculation of sample for an exploratory study is:

$\mathrm{n}=\frac{p(1-p)}{e^{2}} \times 4$

where "p" is the prevalence (i.e. $65 \%$ ), while $\mathrm{e}^{2}$ is the allowed error (taken as 6\%)

The sample size was 253 .

Study Duration: The study was conducted over a period of one year

\section{Inclusion criteria}

- Patients $>18$ years of age.

- Samples of skin scrapping, nail, hair and hair roots were included

\section{Exclusion criteria}

- Patients on antifungal and immunosuppressivetherapy

\section{Methodology}

Specimen Collection- The affected area or lesions was wiped with $70 \%$ alcohol. The specimen includes skin scales, hair, hair roots, nail clippings and scraping beneath the nails. Samples were collected in clean black paper packets.

Skin specimen- Skin specimens were collected by scrapping across the inflamed margin of lesion into the apparently healthy tissue using a curved disposable scalpel blade.

Nail specimen- Clippings were taken from the affected nails using nail clipper. Friable material beneath the nail was also taken by scrapping with disposable scalpel blade.

Hair specimen- Base of the infected hair shaft around the follicle was taken by plucking with epilating forceps.

Specimen processing- Specimens collected were subjected to standard mycological procedures.

Direct Microscopic Examination KOH wet mountThis was prepared by placing portion of each sample collected (skin scales, hair, hair roots, nail clippings and scraping beneath the nails) on a clean, grease free, microscope glass slide.

Then 1-2 drops of $10 \% \mathrm{KOH}$ for the skin and hair sample while $20 \%$ or $40 \% \mathrm{KOH}$ was applied for nail samples. Sample and $\mathrm{KOH}$ was mixed well and a clean cover slip is placed over it, and the slide was gently heated. The slide was allowed to cool and "ripen" a few minutes before examination under bright field microscope under low (XI0) and high (X40) magnification.

The slide was then screened for presence of fungal hyphae which stands out as highly refractile, long undulating, and branched, septate threads or for the presence of arthroconidia which are fragmentation of densely septate hyphae appearing as rectangular or barrel shaped cells.

\section{Results}

In the present study, 354 clinically diagnosed and $\mathrm{KOH}$ positive cases of dermatophytoses attending Skin and venereal disease outpatient Department of HIMS. Barabanki were Studies.

Myccological examination was done in department of Microbiology.

In the present study, most common age group affected $21-30$ years with $37.90 \%$ followed by less than 20 years (21.2\%), 31-40 years $(18.9 \%)$.

Overall, most of the cases of dermatophytoses are in 21-60 years age group while it is least common at extremes of age [Table-1]. Males (81.4\%) were more affected than females (18.6\%).

Male to female ratio was 4.7:1. The higher percentage of males might be due that female much lower enrolled in this study [Table-2]. 
Table-1: Age distribution of patients

\begin{tabular}{|c|c|c|}
\hline Age in years & No. $(\mathbf{n = 3 5 4})$ & \% \\
\hline$\leq 20$ & 75 & 21.2 \\
\hline $21-30$ & 134 & 37.9 \\
\hline $31-40$ & 67 & 18.9 \\
\hline $41-50$ & 45 & 6.8 \\
\hline $51-60$ & 24 & 2.5 \\
\hline$>60$ & 9 & \\
\hline Mean \pm SD (Range) & $31.97 \pm 12.92(19-75)$ & \\
\hline
\end{tabular}

Table- 1 shows the age distribution of patients. More than one third of the patients were between 21-30 (37.9\%) years.

Table-2: Gender distribution of patients

\begin{tabular}{|c|c|c|}
\hline Gender & No $(\mathbf{n = 3 5 4})$ & \% \\
\hline Male & 288 & 81.4 \\
\hline Female & 66 & 18.6 \\
\hline
\end{tabular}

Table-2 shows the gender distribution of patients. Majority of the patients were males (81.4\%).

Table-3: Distribution of patients according to occupation

\begin{tabular}{|c|c|c|}
\hline Occupation & No. $(\mathbf{n = 3 5 4})$ & \% \\
\hline Manal worker & 142 & 40.1 \\
\hline House wife & 112 & 31.6 \\
\hline Student & 41 & 11.6 \\
\hline Professional & 26 & 7.3 \\
\hline Others & 33 & 9.3 \\
\hline
\end{tabular}

Table- 3 shows the distribution of patients according to occupation. More than one third of the patients were manual worker $(40.1 \%)$.

Overall dermatophytoses was most common in manual worker (40.1\% cases) followed by student (31.6\% cases) house wife ( $11.6 \%$ cases) other $(9.3 \%$ cases $)$ and professional $(7.3 \%$ cases $)$.

Table-4: Distribution of patients according to Socio-Economic Status

\begin{tabular}{|c|c|c|}
\hline SES & No. $(\mathbf{n = 3 5 4})$ & \% \\
\hline Lower class & 122 & 34.5 \\
\hline Lower middle class & 184 & 52.0 \\
\hline Middle class & 39 & 11.0 \\
\hline Upper middle class & 9 & 2.5 \\
\hline
\end{tabular}

A total of 354 clinically diagnosed cases of dermatophytosis were studies majority of the case were from lower middle class $(52 \%$ cases) followed by lower class $(34.5 \%$ cases $) \&$ middle class $(25 \%$ cases) upper middle class was least affected with $2.5 \%$ cases respectively. 
Table-5: Distribution of patients according to clinical type.

\begin{tabular}{|c|c|c|}
\hline Clinical type & No. $(n=354)$ & $\%$ \\
\hline Dermatophytosis erythoderma & 1 & 0.3 \\
\hline Eatemsive dermatophytosis & 3 & 0.8 \\
\hline P. psoriasis Nail & 2 & 0.6 \\
\hline T. Barbae & 2 & 0.6 \\
\hline T. Barbae+T.cruris & 2 & 0.6 \\
\hline T. capitis & 3 & 0.8 \\
\hline T.corporis & 16 & 4.5 \\
\hline T. corporis+T.cruris & 170 & 48.0 \\
\hline T. corporis + Tcruris + T.Faciei & 20 & 5.6 \\
\hline T. corporis+T.padis & 3 & 0.8 \\
\hline T. cruris & 90 & 25.4 \\
\hline T. cruris+Dermatitis & 1 & 0.3 \\
\hline T. Faciei & 5 & 1.4 \\
\hline T. Faciei+T.cruris & 7 & 2.0 \\
\hline T. Gladiatorum & 4 & 1.1 \\
\hline T. Incognito & 2 & 0.6 \\
\hline T. Manuum & 2 & 0.6 \\
\hline T. Pedis & 9 & 2.5 \\
\hline T. Manuum+T.pedis & 1 & 0.3 \\
\hline T. Mcognto & 1 & 0.3 \\
\hline T. Unguium & 8 & 2.3 \\
\hline T. Unguium+T.Manuum & 1 & 0.3 \\
\hline T. Carbae+T.corporis + T.cruris & 1 & 0.3 \\
\hline
\end{tabular}

Table-5 shows the distribution of patients according to clinical type. T.corporis+T.cruris was the most common clinical type $(48 \%)$ T.cruris $(25.4 \%)$ was the second most common clinical type.

Table-6: Distribution of patients according to Dermatophytoses infection.

\begin{tabular}{|c|c|c|}
\hline KOH test & No. $(\mathbf{n = 3 5 4})$ & \% \\
\hline Positive & 279 & 78.8 \\
\hline Negative & 75 & 21.2 \\
\hline
\end{tabular}

Table- 6 shows the distribution of patients according to Dermatophytoses infection. Dermatophytoses infection was found to be $78.8 \%$.

Dermatophytoses infection was found to be higher among manual worker $(40.1 \%)$ than house wife $(31.6 \%)$, student (11.6\%), professional and others [Table-3]. Dermatophytoses infection was found to be higher among lower middle class $(52 \%$ cases) followed by lower class $(34.5 \%$ cases $) \&$ middle class $(25 \%$ cases $)$ upper middle class was least affected with $2.5 \%$ cases respectively [Table-4]. T.corporis+T.crurits $(48 \%)$ were the most common clinical type [Table5]. The samples of all clinically diagnosed cases of dermatophytosis were sent to microbiology department where $\mathrm{KOH}$ mount was done. The wet mounts were seen under microscope. Fungal hyphae were seen in only $78.8 \%$ of cases [Table6]. Rests of specimens were negative for $\mathrm{KOH}$. 


\section{Discussion}

Dermatophytoses are superficial infections of keratinized tissue, the skin, hair and nails, caused by dermatophytoses. The prevalence of dermatophytosis is determined by environmental condition, personal hygiene and individual's susceptibility. The variation in clinical presentation is related to the species of the fungus, size of the inoculums, in the involved sites, and the immune status of the host. The higher incidence of superficial mycoses is seen in month of July to September due to rainy season \& humid atmosphere.

Age distribution- Most of the studies from different parts of India reported commonest age- group affected to be 21-30 years [3-7].

The present study was correlated with other studies done by Aurangabad, at Bijapur, at Assam, at Mangalor and at Jammu and Kashmir $[8,9,10]$. High infection of dermatophytosis in this age group (21-60years) might be due to increased physical activity, high chances of exposure and hormonal factors.

Gender distribution- In our study there was male preponderance. Other studies have reported similar observations $[8,9,11]$. Male preponderance might be due to more involvement of them in physical and outdoor activities thereby increasing chance of exposure. Male: Female ratio of 4.7:1 (higher as compared to other studies), may be due to increasing involvement of females nowadays in outdoor activities and increasing health awareness among them.

Occupational status- Manual workers were affected more by dermatophytosis in our study. This was in agreement to the study done by Veer et al [10]. This may be due to more involvement of manual workers in physical activities and thereby increased chance of exposure [12].

Socio-economic status- Patients from lower socioeconomic status were affected more than other in this study. This may be due to poor hygienic conditions, overcrowding, sharing of linen, towels, poor nutrition [13].

Distribution in relation to clinical types- Tinea corpories was the most common clinical type in the study and it was comparable with other study which were done in the past $[9,11,14,15]$. In the present study,
T.cruris (25.4)\% was second most common clinical type. This is comparable to the studies $[9,15,16]$.

In the present study, T.corporis+T.Faciei $(5.6 \%)$ were third most common clinical type. The findings of this study was in agreement with other studies at Mangalore (6\% cases), at Vijaywada $[10,17]$.

Mycological Study by KOH- This indicates that $\mathrm{KOH}$ is only a sensitive and screening test not a specific test to diagnose dermatophytes.

\section{Conclusion}

The present study shows that dermatophytoses infection was found to be higher in the middle age group and was least in the extreme of age. Dermatophytoses infection was found to be higher in males than females. T.corporis+T.cruris were the most common clinical type. T. cruris was the second most common clinical type. Dermatophytoses infection was found to be higher among lower middle class. Dermatophytoses infection was found to be higher among manual worker. $\mathrm{KOH}$ is most common test for rapid confirmation of dermatophytes but it is less specific. Dermatphytoses are quite common in India because of hot and humid climate the poor hygienic conditions, both playing important role in growth of these fungi. There is varying difference in isolation of different species of dermatophytes from different regions of India.

Funding: Nil, Conflict of interest: None initiated, Permission from IRB: Yes

\section{Reference}

1. Rippon JW. Medical mycology- The pathogenic fungi and the pathogenic actionomycetes. $3^{\text {rd }}$ edition. Philadelphia: WB Saunders company; 1988.

2. Chander J. Textbook of medical mycology $3^{\mathrm{r}}$ edition. New Delhi: Mehta Publishers; 2009.

3. Mackenzie DW. The extra-human occurrence of Trichophyton tonsurans var. sulfureum in a residential school. Sabouraudia. 1961 Jan;1:58-64.

4. Kane J, Smitka CM. A practical approach to the isolation and identification of members of the Trichophyton rubrum group. Pan Am. Health Org. Sci. Publ. 1980;396:121-134. 


\section{Research Article}

5. Rebell G, Taplin D. Dermatophytes, their recognition and identification. Coral Gables, Florida: University of Miami Press; 1970.

6. Young CN. Range of variation among isolates of Trichophyton rubrum. Sabouraudia. 1972 Jul; 10(2): 164-70.

7. Kane K, Krajden S, Summerbell RC, Sibbald G. Infections caused by Trichophyton raubitschekii: clinical and epidemiological features. Mycoses 1990; 33: 499-506.

8. Patwardhan N, Dave R. Dermatomycosis in and around Aurangabad. Indian J Pathol Microbiol. 1999 Oct; 42(4):455-62.

9. Sen SS, Rasul ES. Dermatophytosis in Assam. Indian J Med Microbiol. 2006 Jan;24(1):77-8.

10. Kumar S, Malya PS, Kumari P. ClinicoMycological study of dermatophytosis in a tertiary care hospital. International journal of sicentific study 2014;1(6):27-32.

11. Singh S, Beena PM. Profile of dermatophyte infections in Baroda. Indian J Dermatol Venerol Leprol 2003;69:281-3.
12. Chander J. Textbook of medical mycology $3^{r}$ edition. New Delhi: Mehta Publishers; 2009.

13. Gupta S, Agrawal P, Rajawat R, Gupta S. Prevalence of dermatophytic infectino and determining sensitivity of diagnostic procedures. Int J Pharm Pharm Sci 2014;6(3):35-8.

14.B indu V, Pavithran K. Clinico-mycological study of dermatophytosis in Calicut. Indian J Dermatol Venereol Leprol. 2002 Sep-Oct;68(5):259-61.

15. Yadav A, Urhekar AD, Mane V, Danu MS, Goel N, Ajit KG. Optimization and isolation of dermatophytes from clinical samples and in vitro antifungal susceptibility testing by disc diffusion method. RRJMB 2013; 2 (3):19-34.

16. Bhatia VK, Sharma PC. Epidemiological studies on Dermatophytosis in human patients in Himachal Pradesh, India. Springerplus. 2014 Mar 9;3:134. doi: 10.1186/2193-1801-3-134. eCollection 2014.

17. Sarada D, Kumari PR. A study of Dermatomycoses. International Journal of advanced research 2015; 3 (1): 582-8.

\section{How to cite this article?}

Gupta S.K, Prasad J, Brahmane R. B. Clinico-mycological study of Dermatophytosis at a tertiary medical center of Uttar Pradesh. Trop J Path Micro 2017;3(3):283-288.doi: 10.17511/jopm.2017.i3.09. 